\title{
ПРОРАСТАНИЕ СЕМЯН ЗЛАКОВ ПОД ВЛИЯНИЕМ КОМПОЗИЦИЙ АЗОТФИКСИРУЮЩИХ И ФОСФАТМОБИЛИЗУЮЩИХ БАКТЕРИЙ ИЗ ПОЧВ, ВОЗДЕЛЫВАЕМЫХ В УСЛОВИЯХ ДАЛЬНЕГО ВОСТОКА
}

\author{
М.Л. СИДОРЕНКО1, 2 ॠ, Н.А. СЛЕПЦОВА', А.Н. БЫКОВСКАЯ1, \\ В.В. БЕРЕЖНАЯ 3 , А.Г. КЛЫКОВ 3
}

Минеральные удобрения, позволяя значительно увеличить продуктивность сельскохозяйственных культур, при многолетнем использовании оказывают неблагоприятное воздействие на почву и экологию в целом. Микроорганизмы, составляющие основу биопрепаратов, которые рассматривают как альтернативу минеральным удобрениям, стимулируют рост и развитие растений благодаря способности к азотфиксации, продукции сидерофоров, фитогормонов и ферментов, растворению недоступных элементов минерального питания, подавлению фитопатогенов, усилению поглощения влаги и питательных элементов. Однако эффективность таких препаратов сильно зависит от факторов новой для них окружающей среды. Мы предположили, что решением проблемы может стать создание фитостимуляторов на основе бактерий из почв, долгое время подвергавшихся воздействию различных агроприемов. В представленном исследовании нами впервые выделены местные активные штаммы азотфиксирующих и фосфатмобилизующих бактерий из почв длительного (74 года) стационарного опыта по интенсивному земледелию в условиях Дальнего Востока России. Выявлены изоляты и их сочетания с наибольшей потенциальной способностью стимулировать прорастание семян и развитие проростков пшенищы и ячменя. Целью работы было изучение свойств азотфиксирующих и фосфатмобилизующих бактерий из почв, длительное время подвергавшихся активной химизации, как возможных фитостимуляторов. Бактериальные изоляты выделяли из образцов сельскохозяйственных почв (8-е опытное поле ФНЦ Агробиотехнологий им. А.К. Чайки ДВО РАН, Приморский край, Россия), отобранных в октябре 2015 года. В качестве тест-объектов использовали семена пшеницы Triticum aestivum L. copта Приморская 50 и ячменя Hordeum vurlage L. сорта Тихоокеанский (коллекция ФНЦ Агробиотехнологий ДВО РАН). Из 68 бактериальных изолятов с различными культуральными и морфологическими свойствами три (N1, N2 и N3) обладали способностью к азотфиксации и четыре (P6, P7, P8 и Р19) относились к фосфатмобилизующим микроорганизмам. Сравнение результатов применения монокультур и разных вариантов бинарных композиций азотфиксирующих и фосфатмобилизующих изолятов показало, что при обработке энергия прорастания семян пшеницы увеличилась на $13-51 \%(\mathrm{p} \leq \mathbf{0 , 0 5})$, семян ячменя - на $15-54 \%$ (р $\leq \mathbf{0 , 0 5})$ по сравнению с необработанным контролем. Лабораторная всхожесть семян пшеницы под влиянием азотфиксирующих и фосфатмобилизующих бактерий увеличилась на 2-32 \%, семян ячменя - на 7-30\% (по сравнению с необработанным контролем). Обработка семян ячменя в болышинстве вариантов привела к увеличению длины побега в 1,8 раза, длины корней - в 2,7 раза. Наибольшую длину побега (120-140 мм, p $\leq$ 0,05) отмечали для N2P19, Р6P19, P8P19, корней (120-130 мм, p $\leq$ 0,05) - для Р6P7, N2P19, Р6Р19. Полученные результаты позволяют заключить, что краткосрочное замачивание в суспензиях исследуемых азотфиксирующих и фосфатмобилизующих бактерий способствует значительному увеличению энергии прорастания и лабораторной всхожести семян, длины побега и корня. Бинарные композиции бактерий оказывают болышее влияние на прорастание семян растений, чем монокультуры. Наиболее выраженный стимулирующий эффект имели азотфиксирующие штаммы N1 (Acinetobacter spp.), N2 (Azotobacter spp.) и фосфатмобилизующий штамм P19 (Pantoea spp.). При этом наблюдались различия в отзывчивости растений на обработку в зависимости от их видовой принадлежности, вероятно, обусловленные отсутствием генетической и физиолого-биохимической комплементарности между конкретным видом растения и исследуемыми бактериями.

Ключевые слова: биологические удобрения, диазотрофы, фосфатмобилизующие бактерии, почвы, длительная химизация, Triticum aestivum L., пшеница, Hordeum vurlage L., ячмень, семена, энергия прорастания, лабораторная всхожесть, проростки.

Интенсивная эксплуатация сельскохозяйственных земель сопровождается постоянным внесением высоких доз минеральных удобрений $(1,2)$, что позволяет значительно увеличить урожайность, но при многолетнем применении ведет к снижению качества продукции растениеводства, загрязнению окружающей среды, нарушению естественных меха- 
низмов восстановления почв (3-5). Поэтому в настоящее время все чаще вместо минеральных удобрений используются моно-, бинарные и поликомпонентные микробные препараты. В отличие от минеральных удобрений, они имеют ряд преимуществ: не загрязняют окружающую среду, безвредны для человека и животных, не фитотоксичны и не обладают мутагенной активностью, так как представляют собой штаммы естественных почвенных микроорганизмов.

Микроорганизмы, служащие основой биопрепаратов, вступая в тесные взаимодействия с растением-хозяином и другими участниками микробиоценоза, стимулируют рост и развитие растений, используя прямые и непрямые механизмы - фиксацию атмосферного азота, продукцию сидерофоров, фитогормонов и ферментов, растворение недоступных элементов минерального питания (6-8). Некоторые штаммы подавляют развитие фитопатогенных микроорганизмов, обитающих в почве, за счет продукции антимикробных метаболитов (9). Внесение перспективных бактериальных инокулятов способно снижать фитотоксичность почвы, загрязненной тяжелыми металлами $(10,11)$. Посредством обработки микробными препаратами можно добиться повышения стрессоустойчивости растений в условиях засухи за счет усиления поглощения влаги и питательных элементов, а также продукции экзополисахаридов $(12,13)$. Однако эффективность интродуцированных препаратов сильно зависит от факторов новой окружающей среды и способности внесенных микроорганизмов выживать среди индигенных представителей почвенной микрофлоры (14).

Выходом из ситуации может стать создание фитостимуляторов на основе бактерий, выделенных из почв, долгое время подвергающихся воздействию различных агроприемов. Микроорганизмы, сохранившие жизнеспособность в условиях интенсивного земледелия, могут обладать высокой приспособляемостью к почвенно-климатическим условиям возделываемых почв.

В настоящем исследовании из почв длительного стационарного опыта по интенсивному земледелию в условиях Дальнего Востока России мы впервые выделили местные активные штаммы азотфиксирующих и фосфатмобилизующих бактерий и обосновали возможность создания фитостимуляторов на основе таких бактерий.

Цель работы - изучить воздействие азотфиксирующих и фосфатмобилизующих бактерий, выделенных из почв, длительное время подвергавшихся активной химизации, на прорастание семян злаковых культур для последующей разработки биопрепаратов-фитостимуляторов.

Методика. Образцы сельскохозяйственных почв, вовлеченных в длительный опыт (74 года) по внесению удобрений, отбирали в октябре 2015 года (8-е опытное поле ФНЦ агробиотехнологий ДВО РАН) на глубине 5-15 см стерильными инструментами и помещали в стерильную посуду.

Влияние почвенных микроорганизмов на прорастание семян оценивали на пшенице (Triticum aestivum L.) сорта Приморская 50 и ячмене (Hordeum vurlage L.) сорта Тихоокеанский (получены из коллекции ФНЦ агробиотехнологий ДВО РАН).

Штаммы азотфиксирующих и фосфатмобилизующих бактерий выделяли стандартными методами, принятыми в почвенной микробиологии (15). Почвенную суспензию в отношении 1:10 (10 г почвы и 90 мл воды) использовали для приготовления серии последовательных разведений с 
высевом на агаризованные среды: азотфиксирующие микроорганизмы выделяли на среде Эшби (Ashby's Glucose Agar, «HiMedia», Индия), фосфатмобилизующие - на селективной среде с трикальцийфосфатом (16).

Штаммы микроорганизмов, представляющие наибольший интерес, были предварительно идентифицированы как представители Acinetobacter spp. (штамм N1), Azotobacter spp. (штамм N2), Clostridium spp. (штамм N3), Serratia spp. (штамм P6), Bacillus spp. (штамм P7), Arthrobacter spp. (штамм Р8) и Pantoea spp. (штамм Р19).

Рабочие суспензии азотфиксирующих и фосфатмобилизующих бактерий получали культивированием в питательном бульоне (ГРМ-бульон, ФБУН ГНЦ ПМБ, Россия). Численность учитывали с помощью фотоэлектоколориметра AP-101 («APEL Co., Ltd», Япония) при $\lambda=600 \mathrm{HM,}$ для калибровки использовали подсчет микробных клеток в камере Горяева-Тома (микроскоп Axioscop 40, «Carl Zeiss», Германия) (17). После определения исходного количества бактерий для разведения суспензии микробных клеток до рабочей концентрации $1 \times 10^{7} /$ мл использовали физиологический раствор.

Влияние изолятов азотфиксирующих и фосфатмобилизующих бактерий на прорастание семян злаковых растений оценивали по эффекту синергизма в бинарных композициях монокультур. В качестве контроля сравнения использовали стерильный питательный бульон. Контролем опыта выступала водопроводная вода.

Семена растений (по 100 шт. каждого сорта) замачивали 30 мин в тестируемой монокультуре или бинарной композиции изучаемых бактерий. Затем семена раскладывали по 10 шт. на фильтровальной бумаге, смоченной стерильной водой, в стерильные чашки Петри и проращивали при $23{ }^{\circ} \mathrm{C}$. На 3-и сут определяли энергию прорастания, на 7-е сут - лабораторную всхожесть, длину побега и длину корней (18). Опыт проводили в 3-кратной повторности.

Статистическую обработку данных (расчет средних значений $M$, стандартной ошибки средних $\pm \mathrm{SEM}$, параметрическое сравнение по $t$-критерию Стьюдента) проводили с помощью программы SPSS v. 11.5 for Windows (https://spss.software.informer.com/11.5/). Различия считали статистически значимыми при $\mathrm{p} \leq 0,05$.

Результаты. Почва представляет собой систему множества различных микро- и мезосред обитания, обеспечивая условия для развития широкого разнообразия видов почвенных микроорганизмов (19). Способность стимулировать рост и развитие растений отмечена у большого числа микроорганизмов, выделенных из почв, включая представителей родов Azotobacter, Azospirillum, Bacillus, Pseudomonas, Burkholderia, Pantoea spp., Enterobacter (2, 20-22). Эти микроорганизмы способны синтезировать витамины, аминокислоты, полигидроксибутират, фитогормоны, сидерофоры, антибиотики и ферменты, а также фиксировать молекулярный азот и минерализовать фосфаты и другие элементы (23).

Из естественно сложившихся микробных ассоциаций почв полей длительного (74 года) стационарного опыта по химизации (ФНЦ Агробиотехнологий ДВО РАН) мы выделили 68 штаммов бактерий с различными культуральными и морфологическими свойствами. На основе этих изолятов нами создана коллекция азотфиксирующих и фосфатмобилизующих бактерий, скрининг которых по целевым характеристикам (азотфиксация и фосфатмобилизация) выявил семь наиболее активных штаммов, которые использовали в дальнейших экспериментах (табл. 1). 
1. Культурально-морфологические свойства бактериальных изолятов из почв 74-летнего стационарного опыта по химизации (ФНЦ Агробиотехнологий ДВО РАН, Приморский край, 2015 год)

\begin{tabular}{|c|c|c|c|c|c|c|c|}
\hline \multirow{2}{*}{ Признак } & \multicolumn{3}{|c|}{ Азотфиксирующие бактерии } & \multicolumn{4}{|c|}{ Фосфатмобилизующие бактерии } \\
\hline & штамм N1 & штамм N2 & штамм N3 & штамм P6 & штамм P7 & штамм P8 & штамм P19 \\
\hline \multicolumn{8}{|l|}{ Описание колонии: } \\
\hline $\begin{array}{l}\text { размер, мм } \\
\text { поверхность }\end{array}$ & Глянцевая & $\begin{array}{r}5 \\
\text { Глянцевая }\end{array}$ & Глянцевая & Глянцевая $<1$ & Глянцевая ${ }^{1}$ & Глянцевая & Глянцевая \\
\hline цвет & Желтая & Желтоватый & Желтоватый & Белый & Белый & Белый & Желтый \\
\hline прозрачность & - & + & + & - & - & - & - \\
\hline край & Ровный & Мелколопастной & Ровный & Волнистый & Лопастной & Ровный & Ровный \\
\hline профиль & Выпуклая & Выпуклый & Выпуклый & Выпуклый & Выпуклый & Выпуклый & Выпуклый \\
\hline центр & + & - & - & 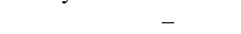 & - & - & - \\
\hline поверхность & Кратерообразная & Ровная & Ровная & Ровная & Ровная & Ровная & Ровная \\
\hline структура & Гладкая & Однородная & Мелкозернистая & Однородная & Мелкозернистая & Мелкозернистая & Однородная \\
\hline консистенция & Легко снимается & Слизистая & Слизистая & Легко снимается & Легко снимается & Легко снимается & Легко снимется \\
\hline \multirow{4}{*}{$\begin{array}{l}\text { Описание клеток: } \\
\text { окрашивание по Граму } \\
\text { форма } \\
\text { размер, мкм }\end{array}$} & & & & & & & \\
\hline & - & - & - & - & - & - & - \\
\hline & Палочки & Палочки & Палочки & Короткие палочки & Короткие палочки & Короткие палочки & Палочки \\
\hline & $1 \times 0,5$ & $0,8 \times 0,4$ & $0,8 \times 0,3$ & $1 \times 1,5$ & $1,2 \times 1,8$ & $1,2 \times 1,8$ & $1 \times 0,4$ \\
\hline
\end{tabular}


В нашем эксперименте рабочие суспензии микроорганизмов сочетали между собой в соотношении 1:1, в результате чего получили 28 бинарных композиций и монокультур азотфиксирующих и фосфатмобилизующих бактерий (табл. 2).

2. Схема комбинаций азотфиксирующих и фосфатмобилизующих бактерий, использованных в эксперименте

\begin{tabular}{|c|c|c|c|c|c|c|c|}
\hline \multirow{2}{*}{ Штамм } & \multicolumn{3}{|c|}{ Азотфиксирующие бактерии } & \multicolumn{4}{|c|}{ Фосфатмобилизующие бактерии } \\
\hline & N1 & $\mathrm{N} 2$ & N3 & P6 & P7 & P8 & P19 \\
\hline \multicolumn{8}{|c|}{ Азотфиксирующие бактерии: } \\
\hline N1 & + & + & + & + & + & + & + \\
\hline $\mathrm{N} 2$ & - & + & + & + & + & + & + \\
\hline N3 & - & - & + & + & + & + & + \\
\hline \multicolumn{8}{|c|}{ Фосфатмобилизующие бактерии: } \\
\hline P6 & - & - & - & + & + & + & + \\
\hline P7 & - & - & - & - & + & + & + \\
\hline P8 & - & - & - & - & - & + & + \\
\hline P19 & - & - & - & - & - & - & + \\
\hline \multicolumn{8}{|c|}{$\begin{array}{l}\text { П р и м е ч а н и е. Штаммы предварительно идентифицированы как представители Acinetobacter spp. (N1), } \\
\text { Azotobacter spp. (N2), Clostridium spp. (N3), Serratia spp. (P6), Bacillus spp. (P7), Arthrobacter spp. (P8) и Pantoea } \\
\text { spp. (P19). }\end{array}$} \\
\hline
\end{tabular}
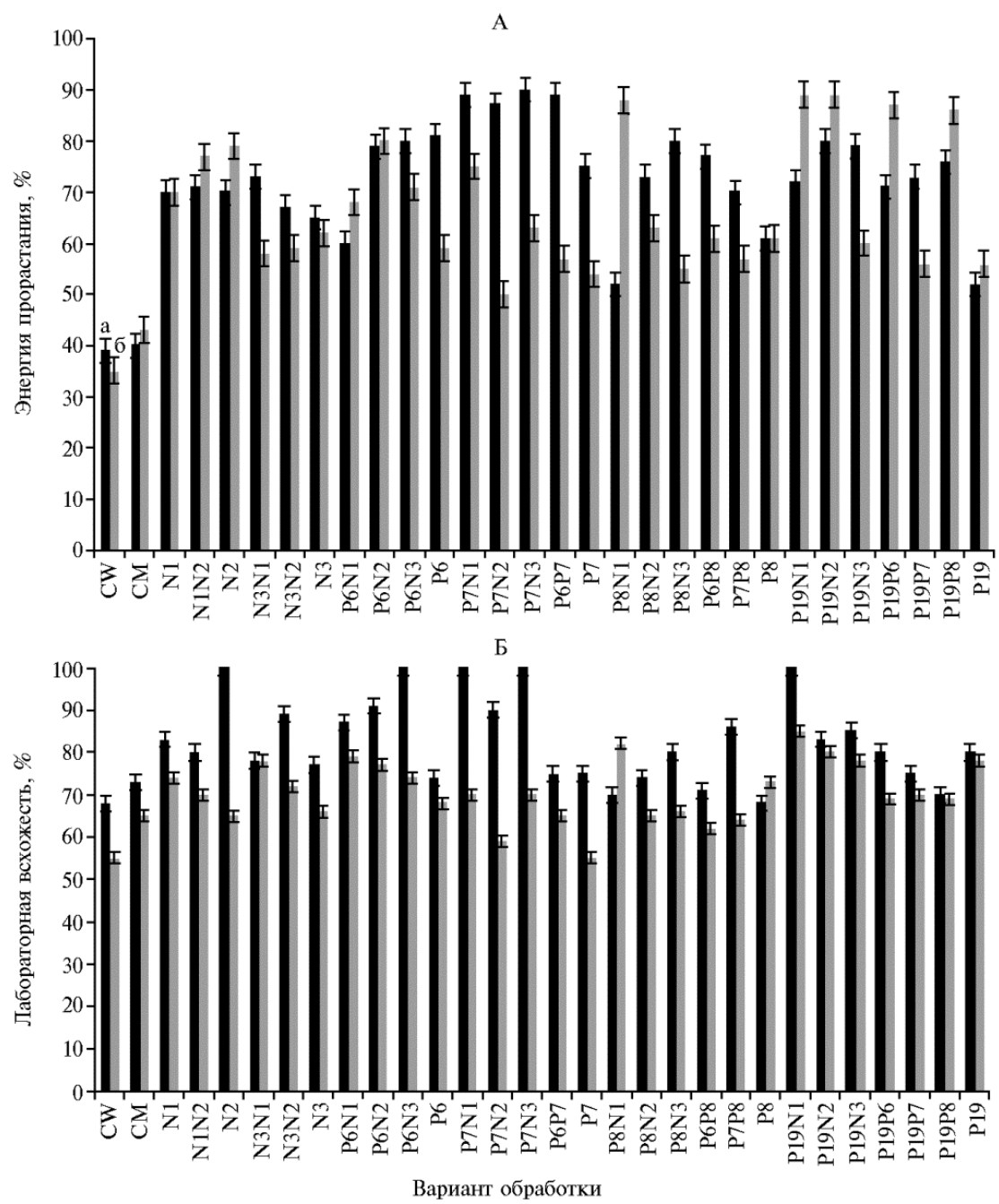

Рис. 1. Энергия прорастания (А) и лабораторная всхожесть (Б) семян у пшеницы (Triticum aestivum L.) сорта Приморская 50 (а) и ячменя (Hordeum vurlage L.) сорта Тихоокеанский (б) при обработке культурами бактериальных изолятов: штаммы N1 (Acinetobacter spp.), N2 (Azotobacter spp.), N3 
(Clostridium spp.) (азотфиксирующие бактерии), P6 (Serratia spp.), P7 (Bacillus spp.), P8 (Arthrobacter spp.), P19 (Pantoea spp.) (фосфатмобилизующие бактерии); CW - контроль (вода), $\mathrm{CM}-$ контроль (питательная среда) $(N=3, M \pm \mathrm{SEM})$. Для всех вариантов различия статистически значимы при $\mathrm{p} \leq 0,05$.

Было установлено, что в результате обработки семенного материала исследуемыми бактериями энергия прорастания и лабораторная всхожесть варьируют в зависимости от варианта опыта и вида растения. Так, у пшеницы и ячменя энергия прорастания семян в контроле составила соответственно 39 и $35 \%$, в контроле сравнения - 40 и 43 \%, тогда как при обработке азотфиксирующими и фосфатмобилизующими бактериями этот показатель увеличился у пшеницы - на 13-51 \%, у ячменя - на 15-54 \% по сравнению с необработанным контролем. У семян пшеницы энергия прорастания была наибольшей в вариантах N1P7, N3P7 и P7P6, у ячменя - N1P8, N1P19 и N2P19 (рис. 1).

Лабораторная всхожесть семян у пшеницы и ячменя в необработанном контроле составила соответственно 68 и $55 \%$, в контроле сравнения 73 и $65 \%$, при обработке азотфиксирующими и фосфатмобилизующими бактериями - повышалась соответственно на 2-32 \% и 7-30 \% по сравнению с контролем без обработки. Полную всхожесть (100 \%) семян пшеницы отмечали при применении бинарных комбинаций N3P6, N3P7, N1P19, а также монокультуры N2. Наибольшие значения показателя лабораторной всхожести семян (80-85 \%) у ячменя наблюдали в вариантах N2P19, N1P8 и N1P19 (см. рис. 1).

Изучение влияния исследуемых микроорганизмов на рост и развитие проростков пшеницы выявило следующие достоверные $(\mathrm{p} \leq 0,05)$ морфометрические изменения относительно контрольных вариантов (разница между контролями была незначительной и лежала в пределах ошибки опыта): увеличение длины побега - на 20,9 \%, длины корня - на 83,7 \%. Максимальные значения длины побега регистрировали в вариантах N2N3 (86,4 мм), N1P8 (87,4 мм) и N2P19 (88,3 мм) (рис. 2), корня - N1N2 (165,4 мм), N2 (159,1 мм) и P19N3 (148,0 мм). В некоторых вариантах длина побега уменьшалась на 5,2 \%, длины корня - 17,4 \% по сравнению с контролями $(\mathrm{p} \leq 0,05)$.

Обработка семян ячменя штаммами азотфиксирующих и фосфатмобилизующих бактерий в большинстве вариантов также привела к увеличению длины побега в 1,8 раза, корней - в 2,7 раза $(\mathrm{p} \leq 0,05)$. Наибольшую длину побега отмечали в вариантах, обработанных комбинациями бактерий N2P19 (140,0 мм), P6P19 (121,0 мм), P8P19 (120,0 мм), максимальную длину корней - при обработке суспензиями бактерий Р6P7 (119,2 мм), N2P19 (121,1 мм), Р6Р19 (132,8 мм) (см. рис. 2). Как и с пшеницей, у ячменя в некоторых случаях наблюдалось уменьшение морфометрических характеристик: длины побега - на 36,7 \%, длины корня - на 46,7 \% по сравнению с контрольными вариантами, $(\mathrm{p} \leq 0,05)$. Интересно отметить, что комбинация N3P7, обработка которой положительно влияла на энергию прорастания и лабораторную всхожесть семян (особенно у пшеницы), способствовала уменьшению длины побега и корня как у ячменя, так и у пшеницы. У разных культур отзывчивость прорастающих семян на обработку одной и той же комбинацией бактерий была неодинаковой. Так, пара изолятов Р6Р7 заметно стимулировала рост побега и корней у ячменя, но не оказывала значительного влияния на эти характеристики у пшеницы.

Для сочетания N2P8 эффект был обратным: у проростков пшеницы длина побега и корня увеличивалась заметно, тогда как у проростков 
ячменя - незначительно и даже в ряде случаев уменьшалась по сравнению с контролем $(\mathrm{p} \leq 0,05)$. Так, мы отмечали увеличение длины побега и корня у пшеницы относительно обоих контролей, при этом относительно одного контроля (питательный бульон) оно было больше (побеги - на 12 мм, корни - на 50 мм), относительно другого (вода) - меньше (побеги - на 10 мм, корни - на 47 мм). У ячменя эти показатели в целом уменьшились по отношению к обоим контролям, но неодинаково: в сравнении с вариантом с водой отмечали уменьшение длины побегов на 6 мм и увеличение длины корней на 3 мм, по отношению к контролю сравнения (питательный бульон) побеги были длиннее на 4 мм, корни - на 3 мм.
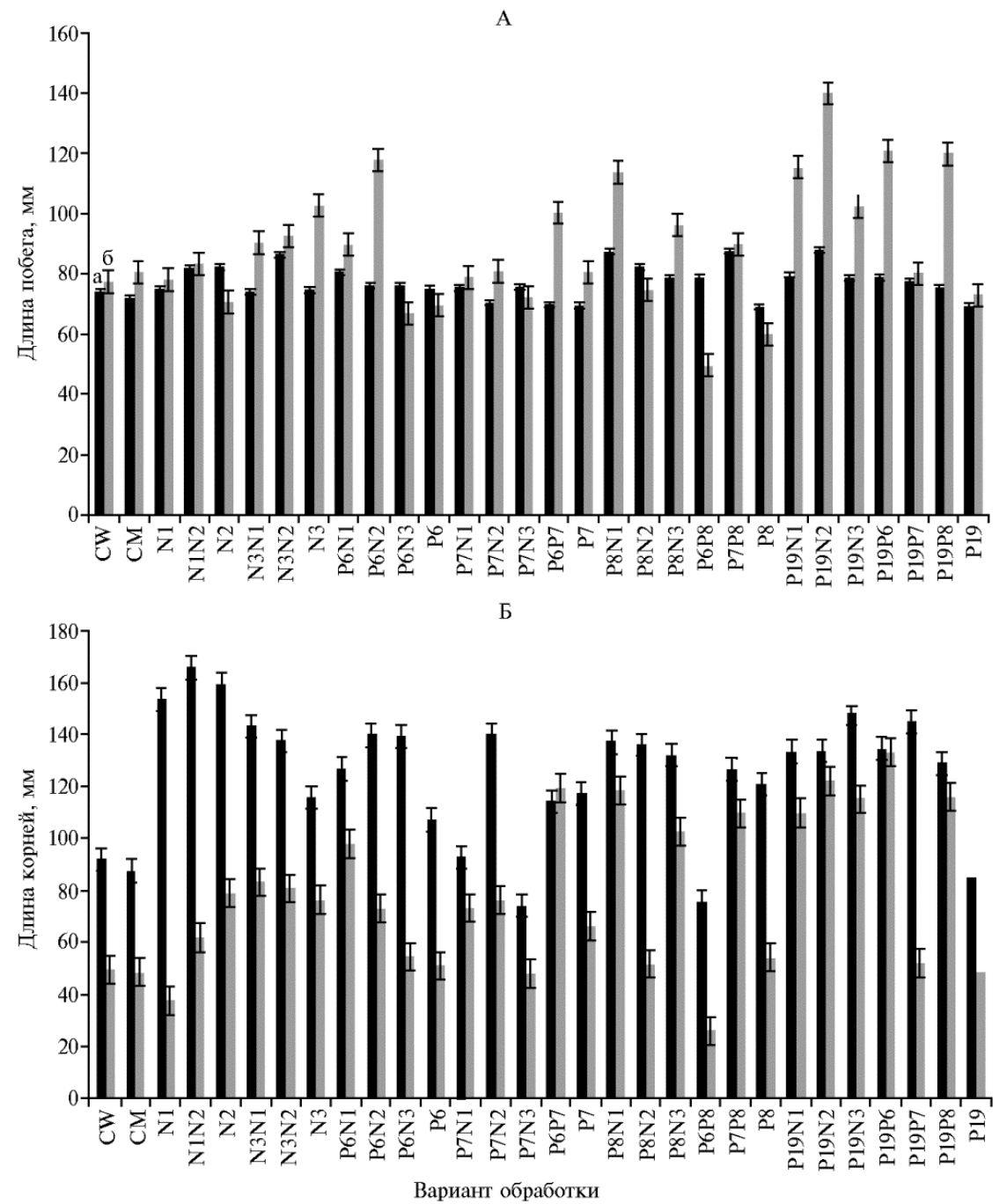

Рис. 2. Длина побега (А) и длина корней (Б) семян у пшеницы (Triticum aestivum L.) copта Приморская 50 (а) и ячменя (Hordeum vurlage L.) сорта Тихоокеанский (б) при обработке культурами бактериальных изолятов: штаммы N1 (Acinetobacter spp.), N2 (Azotobacter spp.), N3 (Clostridium spp.) (азотфиксирующие бактерии), P6 (Serratia spp.), P7 (Bacillus spp.), P8 (Arthrobacter spp.), P19 (Pantoea spp.) (фосфатмобилизующие бактерии); CW - контроль (вода), $\mathrm{CM}$ - контроль (питательная среда) $(N=3, M \pm \mathrm{SEM}$, лабораторный опыт). Для всех вариантов различия статистически значимы при $\mathrm{p} \leq 0,05$.

Энергия прорастания и всхожесть семян - важные показатели конкурентоспособности растений, влияющей на их развитие и урожайность (24). Мы показали, что обработка семян пшеницы и ячменя суспензиями 
исследуемых азотфиксирующих и фосфатмобилизующих изолятов способствовала значительному и достоверному $(\mathrm{p} \leq 0,05)$ увеличению энергии прорастания и лабораторной всхожести. Наиболее выраженный стимулирующий эффект имели комбинации бактерий, включающие штаммы N1, N2, P7, P19. L. Hahn с соавт. (22) в стерильных условиях обрабатывали семена риса Oryza sativa L. жидкими культурами, содержащими азотфиксирующие бактерии родов Burkholderia u Mesorhizobium. Опыты показали (22), что начальная всхожесть, рассчитанная как процент семян, проросших на 3-и сут, от числа семян, проросших на 6-е сут, в вариантах с обработкой увеличилась на 20-38 \% по сравнению с контролем. Значительное повышение лабораторной всхожести кукурузы отмечали при применении азотфиксирующих бактерий родов Pseudomonas, Bacillus, Enterobacter и Pantoea (21).

Лабораторная всхожесть и полевая всхожесть могут различаться. Например, в экспериментах S. Batool и A. Iqbal (25) повышение всхожести обеззараженных семян пшеницы, обработанных различными штаммами фосфатсолюбилизирующих бактерий и проращиваемых в чашках Петри, по отношению к контролю составило 65-90 \%, тогда как в полевых условиях при выращивании в вегетационных сосудах показатель по сравнению с контролем увеличился на 20-80 \%. Подобные расхождения могут быть связаны с резко различающимися условиями среды и, как следствие, с изменением характера взаимодействий в системе растение-микроорганизмы. В то же время возможны и достаточно стабильные взаимодействия: все исследованные в эксперименте фосфатсолюбилизирующие бактерии положительно влияли на развитие растений пшеницы и рекомендованы авторами в монокультуре или в консорциуме как альтернатива минеральным удобрениям (25). Сообщалось, что инокуляция семян биопрепаратами, содержащими живые микроорганизмы, положительно влияет на всхожесть, при этом эффект зависит от погодных условий, сопутствующих началу вегетации (26). Очевидно, что для обеспечения положительного результата при микробнорастительном взаимодействии необходимо, чтобы интродуцированные микроорганизмы не ингибировали рост и развитие растения-партнера. Выявить стимулирующее или ингибирующее воздействие бактерий на развитие растений ячменя Hordeum vulgare L., яровой пшеницы Triticum aestivum L., ржи Secale cereale можно уже на стадии прорастания семени (2). По данным литературы, эффект ингибирования развития растений может быть связан с высокой концентрацией фитогормона индолил-3-уксусной кислоты, который в низких концентрациях стимулирует рост (27). В лабораторных условиях ингибирующее действие ассоциативных диазотрофов на прорастающие семена могло проявляться вследствие отсутствия или недостатка в среде элементов питания, необходимых для размножения этой группы микроорганизмов. Как известно, ризосферные бактерии потребляют главным образом выделяемые прорастающими семенами продукты обмена, но в отсутствие фотосинтеза их количество невелико (20).

Комбинации исследуемых нами бактерий в большинстве вариантов в разной степени способствовали увеличению длины побега и длины корня у проростков обоих видов растений $(\mathrm{p} \leq 0,05)$. Увеличение длины корней отмечено при обработке семян пшеницы бактериями рода Bacillus (28). Наиболее выраженное стимулирующее действие в отношении этих морфометрических характеристик оказали комбинации, включавшие штаммы Р19, N1, N2, причем бинарные композиции, включавшие и азотфиксирующие, и фосфатмобилизующие бактерии, проявили в целом более выраженный эффект, чем монокультуры тех же микроорганизмов. Подобное наблюдали 
S. Widawati и S. Suliasih (29), изучая влияние бактерий родов Azotobacter, Azospirillum и Bacillus на прорастание семян сорго Sorghum bicolor L., установили, что показатели энергии прорастания, длины побега и корня при инокуляции монокультурами даже снижались относительно контроля (исключением оказался вариант с обработкой Azospirillum lipoferum). В то же время одновременная обработка азотфиксирующими бактериями рода Rhizobium и фосфатрастворяющими бактериями рода Pseudomonas способствовала увеличению массы корней, побегов и урожайности пшеницы (30).

Отметим, что влияние исследуемых нами бактериальных инокулятов на прорастание семян зависело от вида растения. Так, в варианте N1P8 обработка не оказала заметного влияния на семена пшеницы, но в опыте с ячменем эта же бинарная композиция обеспечила максимальные значения энергии прорастания и лабораторной всхожести семян. Сходную закономерность наблюдали для варианта N1P7, однако в этом случае наибольший стимулирующий эффект отмечен нами для пшеницы. Сообщалось (31), что по урожайности ячмень отзывчивее пшеницы на обработку препаратом Ризоагрин. Более того, для сои отмечены сортовые различия при обработке штаммами Bacillus subtilis. Подобное может быть связано с синтезом некоторых метаболитов, эффективность использования которых напрямую зависит от генотипа растения и его жизненного цикла (32).

Таким образом, установлено, что обработка семян пшеницы и ячменя суспензиями изолятов азотфиксирующих и фосфатмобилизующих бактерий, выделенных из почв, подвергавшихся многолетней (74 года) систематической обработке минеральными удобрениями, способствовала значительному увеличению энергии прорастания и лабораторной всхожести семян, длины побега и корня. Показано, что энергия прорастания семян пшеницы в вариантах, обработанных азотфиксирующими и фосфатмобилизующими бактериями, увеличилась в среднем на $32 \%$ (от 13 до $51 \%$ ) (p $\leq 0,05)$, семян ячменя - в среднем на $34,5 \%$ (от 15 до $54 \%)(\mathrm{p} \leq 0,05)$ по сравнению с необработанным контролем. При этом лабораторная всхожесть семян пшеницы в вариантах с обработкой бактериями, способными к азотфиксации и фосфатмобилизации, увеличилась на 2-32\% (p $\leq 0,05)$, семян ячменя - на 7-30 \% (p $\leq 0,05)$ по сравнению с необработанным контролем. Наибольшую длину побега отмечали при применении комбинаций N2P19, P6P19, P8P19, корней - для сочетаний Р6P7, N2P19, Р6P19. Бинарные композиции бактерий оказали большее влияние на прорастание семян растений, чем монокультуры. Наиболее выраженный стимулирующий эффект проявили комбинации, включавшие азотфиксирующие штаммы N1 (Acinetobacter spp.), N2 (Azotobacter spp.) и фосфатмобилизующий штамм P19 (Pantoea spp.). При этом наблюдались различия в отзывчивости растений на обработку в зависимости от видовой принадлежности, вероятно, обусловленные отсутствием генетической и физиолого-биохимической комплементарности между конкретным видом растения и исследуемым изолятом или их сочетанием. В дальнейшем мы планируем изучить эффективность этих бактериальных инокулятов в вегетационных опытах и в полевых условиях.

1 ФНЦ биоразнообразия наземной биоты

Восточной Азии ДВО РАН,

690022 Россия, г. Владивосток, Пр-т 100-летия Владивостока, 159,

e-mail: sleptsova-n@bk.ru, anastasia_n.boyko@inbox.ru;

2ФГАОУ ВО Дальневосточный федеральный университет, 690922 Россия, Приморский край, г. Владивосток, о. Русский,

п. Аякс, 10,

e-mail: sidorenko@biosoil.ru $\bowtie$;
Поступила в редакцию 12 ноября 2019 года 


\title{
EFFECTS OF NITROGEN-FIXING AND PHOSPHATE-SOLUBILIZING MICROORGANISMS FROM THE FAR EAST AGRICULTURAL SOILS ON THE CEREAL SEED GERMINATION
}

\author{
M.L. Sidorenko ${ }^{1,2}{ }^{凶}$, N.A. Sleptsova ${ }^{1}$, A.N. Bykovskaya1, V.V. Berezhnaya ${ }^{3}$, A.G. Klykov ${ }^{3}$ \\ 1 Federal Scientific Center of the East Asia Terrestrial Biodiversity, Far Eastern Branch RAS, 159, Prosp. 100-letiya \\ Vladivostoka, Vladivostok,690022 Russia, e-mail sleptsova-n@bk.ru, anastasia_n.boyko@inbox.ru; \\ ${ }^{2}$ Far Eastern Federal University, Campus, 10 Ajax Bay, Russky Island, Vladivostok, 690922 Russia, e-mail \\ sidorenko@biosoil.ru (凹 corresponding author); \\ ${ }^{3}$ Chaika Federal Scientific Center of Agrobiotechnology in the Far East, Far Eastern Branch RAS, 30, ul. Volozhenina, \\ Ussuriysk, 692539 Russia, e-mail bereg911@mail.ru, alex.klykov@mail.ru
} ORCID:

Sidorenko M.L. orcid.org/0000-0002-4035-8395 Sleptsova N.A. orcid.org/0000-0002-4226-1984

Bykovskaya A.N. orcid.org/0000-0002-0584-8882

The authors declare no conflict of interests

Received November 12, 2019

Berezhnaya V.V. orcid.org/0000-0002-2086-0943

Klykov A.G. orcid.org/0000-0002-2390-3486

doi: 10.15389/agrobiology.2021.1.146eng

\section{Abstract}

Mineral fertilizers which can significantly increase crop productivity have an adverse effect on the soil and the environment as a whole when used for a long time. Microorganisms, as an alternative to mineral fertilizers, stimulate plant growth and development due to their ability to fix nitrogen, produce siderophores, phytohormones and enzymes, dissolve inaccessible elements of mineral nutrition, suppress plant pathogens, and increase consumption of water and nutrients. However, the effectiveness of such preparations highly depends on factors of a new environment. We believe that bacteria from soils that have long been exposed to various agricultural practices may be good plant stimulants. In the presented study, for the first time, we have isolated local active strains of nitrogen-fixing and phosphate-mobilizing bacteria from soils subjected to 74-year stationary intensive farming in the conditions of the Russian Far East and revealed isolates and their combinations which stimulate wheat and barley seed germination and seedling growth. The aim of the work was to study the plant-stimulating properties of nitrogen-fixing and phosphate-mobilizing bacteria from soils that have been actively exposed to mineral fertilizers for a long time. Bacteria were isolated from soils sampled in October 2015 (the experimental field 8, Federal Research Center for Agrobiotechnology FEB RAS, Ussuriysk, Primorsky Territory, Russia). The seeds of wheat Triticum aestivum L. cultivar Primorskaya 50, and barley Hordeum vurlage L. cultivar Tikhookeanskii (collection of the Federal Research Center for Agrobiotechnology FEB RAS) were treated. Of 68 bacterial isolates with different cultural and morphological properties, three isolates, the Acinetobacter spp. N1, Azotobacter spp. N2, and Clostridium spp. N3 were nitrogen fixers, and four isolates, the Serratia spp. P6, Bacillus spp. P7), Arthrobacter spp. P8, and Pantoea spp. P19 were phosphate-mobilizing bacteria. Tests with the monocultures of nitrogen-fixing and phosphate-mobilizing isolates and their different binary compositions showed a $13-51 \%$ increase $(\mathrm{p} \leq 0.05)$ in wheat seed germination energy and $15-54 \%$ increase $(\mathrm{p} \leq 0.05)$ in barley seed germination energy compared to the untreated control. Laboratory germination of wheat seeds increased by $2-32 \%$, barley seeds by 7-30\% compared to untreated control. The barley seedlings were 1.8 times longer, and the roots were 2.7 times longer. Th binary combination N2P19, P6P19, and P8P19 caused the highest height of seedlings $(120-140 \mathrm{~mm}, \mathrm{p} \leq 0.05)$, and with $\mathrm{P} 6 \mathrm{P} 7, \mathrm{~N} 2 \mathrm{P} 19$, and $\mathrm{P} 6 \mathrm{P} 19$ the roots were the longest $(120-130 \mathrm{~mm}, \mathrm{p} \leq 0.05)$. These results allow us to conclude that short-term soaking seeds in the suspensions of the tested nitrogen-fixing and phosphate-mobilizing isolates improves seed germination energy and laboratory germination, and increases shoot and root length. Binary bacterial compositions have a greater effect on seed germination than monocultures. The strains N1 (Acinetobacter spp.), N2 (Azotobacter spp.), and P19 (Pantoea spp.) are the best stimulants. Species-specific differences in plant response to the treatment is probably due to lack of genetic, biochemical and physiological complementarities between specific plant species and the bacteria.

Keywords: biological fertilizers, diazotrophs, phosphate-mobilizing bacteria, soil, long-term chemicalization, Triticum aestivum L., wheat, Hordeum vurlage L., barley, seeds, germination energy. laboratory germination, seedlings. 


\section{REFEREN C ES}

1. Lissaletta L., Billen G., Garnier J., Bouwman L., Velazquez E., Mueller N.D., Gerber J.S. Nitrogen use in the global food system: past trends and future trajectories of agronomic performance, pollution, trade, and dietary demand. Environmental Research Letters, 2016, 11(9): 1-15 (doi: 10.1088/1748-9326/11/9/095007).

2. Aleshchenkova Z.M., Safronova G.V., Mel'nikov N.V., Esenbaeva A.E., Ten O.A. Vestnik Bashkirskogo universiteta, 2015, 20(1): 82-86 (in Russ.).

3. Matin X.M., Sumathi C.S., Kannan V.R. Influence of agrochemical and Azotobacter spp. application on soil fertility in relation to maize growth under nursery conditions. Eurasian Journal of BioSciences, 2011, 5(1): 19-28 (doi: 10.15580/GJAS.2014.4.010314003).

4. Korshunova T.Yu., Silishchev N.N., Loginov O.N., Monakov Yu.B. Vestnik Bashkirskogo universiteta, 2007, 12(3): 34-35 (in Russ.).

5. Savci S. An agricultural pollutant: chemical fertilizer. International Journal of Environmental Science and Development, 2012, 3(1): 77-79 (doi: 10.7763/IJESD.2012.V3.191).

6. Gamzaeva R.S. Izvestiya Sankt-Peterburgskogo gosudarstvennogo agrarnogo universiteta, 2015, 40: 38-41 (in Russ.).

7. Ahmemad M., Khan M.S. Alleviation of fungicide-induced phytotoxicity in greengram [Vigna radiata (L.) Wilczek] using fungicide-tolerant and plant growth promoting Pseudomonas strain. Saudi Journal of Biological Sciences, 2012, 19(4): 451-459 (doi: 10.1016/j.sjbs.2012.06.003).

8. Lukin S.M., Marchuk E.V. Dostizheniya nauki i tekhniki APK, 2011, 8: 18-21 (in Russ.).

9. Nelson L.M. Plant growth promoting rhizobacteria (PGPR): prospects for new inoculants. Crop Management, 2004, 3(1): 301-305 (doi: 10.1094/CM-2004-0301-05-RV).

10. Shabaev V.P. Agrokhimiya, 2016, 8: 82-87 (in Russ.).

11. Tirry N., Tahry Joutey N., Sayel H., Kouchou A., Bahafid W., Asri M., El Ghachtouli N. Screening of plant promoting traits in heavy metals resistant bacteria: prospects in phytoremediation. Journal of Genetic Engineering and Biotechnology, 2018, 16(2): 613-619 (doi: 10.1016/j.jgeb.2018.06.004).

12. Espidicar Z., Yarnia M., Ansari M., Mirshekari B., Asadi Rahmani H. Differences in nitrogen and phosphorus uptake and yield components between barley cultivars grown under arbuscular mycorrhizal fungus and pseudomonas strains co-inoculation in rainfed condition. Applied Ecology and Environmental Research, 2017, 15(4): 195-216 (doi: 10.15666/aeer/1504_195216).

13. Fukami J., Cerezini P., Hungria M. Azospirillum: benefits that go far beyond biological nitrogen fixation. $A M B$ Express, 2018, 8(1): 73 (doi: 10.1186/s13568-018-0608-1).

14. Martínez-Viveros O., Jorquera M.A., Crowley D.E., Gajardo G., Mora M.L. Mechanisms and practical considerations involved in plant growth promotion by Rhizobacteria. Jornal of Soil and Plant Nutrition, 2010, 10(3): 293-319 (doi: 10.4067/S0718-95162010000100006).

15. Hazan R., Que Y.A., Maura D., Rahme L.G. A method for high throughput determination of viable bacteria cell counts in 96-well plates. BCM Microbiology, 2012, 12(1): 259 (doi: 10.1186/1471-218012-259).

16. Hanaka A., Ozimek E., Majewska M., Anna Rysiak A., Jaroszuk-Ściseł J. Physiological diversity of Spitzbergen soil microbial communities suggests their potential as Plant Growth-Promoting Bacteria. International Journal of Molecular Sciences, 2019, 20(5): 1207 (doi: 10.3390/ijms20051207).

17. Pruntova O.V., Sakhno O.N. Laboratornyi praktikum po obshchei mikrobiologii [Laboratory course in general microbiology]. Vladimir, 2005 (in Russ.).

18. Bome N.A., Belozerova A.A., Bome A.Ya. Biologicheskie svoistva semyan i fenogeneticheskii analiz kul'turnykh rastenii [Biological properties of seeds and phenogenetic analysis of cultivated plants]. Tyumen', 2007 (in Russ.).

19. Zvyagintsev D.G. Pochva i mikroorganizmy [Soil and microorganisms]. Moscow, 1987 (in Russ.).

20. Zolotarev V.N. Agrokhimiya, 2015, 7: 11-16 (in Russ.).

21. Kifle M.H., Laing D.M. Effects of selected diazotrophs on maize growth. Frontiers in Plant Science, 2016, 7: 1429 (doi: 10.3389/fpls.2016.01429).

22. Hahn L., de Sá E.L.S., Osyrio Filho B.D., Machado R.G., Damasceno R.G., Giongo A. Rhizobial inoculation, alone or coinoculated with Azospirillum brasilense, promotes growth of wetland rice. Revista Brasileira de Ciência do Solo, 2016, 40: e0160006 (doi: 10.1590/18069657rbcs20160006).

23. Myresiotis C.K., Vryzas Z., Papadopoulou-Mourkidou E. Biodegradation of soil applied pesticides by selected strains of plant growth promoting rhizobacteria (PGPR) and their effects on bacterial growth. Biodegradation, 2012, 23(2): 297-310 (doi: 10.1007/s10532-011-9509-6).

24. Sochorec M.R., Knot P. The effect of fertilizer seed coating on the germinating capacity and initial development of some turf grass species and white clover. Acta Universitatus et Silviculturae Mendeliane Brunensis, 2012, 60(5): 199-204 (doi: 10.11118/actaun201260050199).

25. Batool S., Iqbal A. Phosphate solubilizing rhizobacteria as alternative of chemical fertilizer for growth and yield of Triticum aestivum (Var. Galaxy 2013). Saudi Journal of Biological Sciences, 2019, 26(7): 1400-1410 (doi: 10.1016/j.sjbs.2018.05.024).

26. Zavalin A.A. Biopreparaty, udobreniya i urozhai [Biopreparations, fertilizers and crop]. Moscow, 2005 (in Russ.). 
27. Xie H., Pasternak J.J., Glick B.R. Isolation and characterization of mutants of the plant growthpromoting rhizobacterium Pseudomonas putida CR12-2 that overproduce indoleacetic acid. Current Microbiology, 1996, 32(2): 67-71 (doi: 10.1007/s002849900012).

28. Mnasri N., Chennaoui C., Gargouri S., Mhamdi R., Hessini K., Elkahoui S., Djebali N. Efficacy of some rhizospheric and endophytic bacteria in vitro and as seed coating for the control of Fusarium culmorum infecting durum wheat in Tunisia. European Journal of Plant Pathology, 2017, 147(3): 501-515 (doi: 10.1007/s10658-016-1018-3).

29. Widawati S., Suliasih S. The effect of plant growth promoting rhizobacteria (PGPR) on germination and seedling growth of Sorghum bicolor L. Moench. IOP Conf. Series: Earth and Environmental Science, 2018, 166(1): 012022 (doi: 10.1088/1755-1315/166/1/012022).

30. Afzal A., Bano A. Rhizobium and phosphate solubilizing bacteria improve the yield and phosphorus uptake in wheat (Triticum aestivum). International Journal of Agriculture and Biology, 2008, 10(1): 85-88.

31. Kuz'min N.A., Seitova O.V. Vestnik Ryazanskogo gosudarstvennogo agrotekhnicheskogo universiteta im. P.A. Kostycheva, 2010, 2: 27-30 (in Russ.).

32. Costa L.C., Tavanti R.F.R., Tavanti T.R., Pereira C.S., Desenvolvimento de cultivares de soja após inoculação de estirpes de Bacillus subtilis. Nativa, 2019, 7(2): 126-132 (doi: 10.31413/nativa.v7i2.6261). 